\title{
NEUROIMAGING STUDIES ON DRAWING SUGGEST A LINK BETWEEN SYMBOLIC BEHAVIOR TO LANGUAGE: A POTENTIAL HINT TO THE NEANDERTHAL LANGUAGE CONTROVERSY
}

\author{
Michiru Makuuchi * \\ *Corresponding Author: makuuchi-michiru@rehab.go.jp \\ Neuropsychology, National Rehabilitation Center \\ for Persons with Disabilities, Tokorozawa, Japan
}

The absence of symbolic behaviors has often been associated with the lack of language in the Neanderthals. However, the conceptual link between symbolic behavior and language is simply speculative, therefore it calls for more convincing arguments (Balari, et al., 2011; Berwick, et al., 2013). Regarding the differences in the symbolic behaviors in the two species, drawing shows a striking contrast probably because its privileged position for preservation compared to other symbolic behaviours such as gesture, music, dance, and ritual. The homo sapiens have demonstrated their competence for symbolic behavior by depicting figurative pictures such as humans and animals on cave walls in Europe and Indonesia as early as 40 kyr ago (Aubert, et al., 2014). In contrast, clear archeological records for the Neanderthal artefacts is extremely scanty (Higham, et al., 2010), except stone and bone tools (Soressi, et al., 2013) (but see (Hoffmann, et al., 2018; Jaubert, et al., 2016)). This discrepancy becomes more impressive when we take into account of their temporal overlap estimated 2,600-5,400 yrs (Higham, et al., 2014) or of their direct and perhaps intimate interaction implied by the gene flow from the Neanderthals to the modern humans (Prufer, et al., 2014). The absence of evidence is not the evidence of absence, and drawing might be done on sand or on other frail materials, but the lack of drawing works in Neanderthal's sites is notable when we consider discovery of thousands of their fossils. How do cognitive abilities that create figurative art relate to language faculty? Recent neuroimaging studies on drawing may hold a useful clue to this question. 
Neuroimaging is a technique to measure brain activities during various perceptual or cognitive tasks. Functional magnetic resonance imaging (fMRI) is the most popular method among others since it allows the best spatial resolution in localizing activated loci in the brain without any invasion to the body. Several studies on the brain mechanisms of drawing have revealed that drawing activates a network of brain regions. The first study aimed at examining the laterality of activation in the parietal lobes which was the main regions for drawing deficits when the brain is insulted (De Renzi, 1997; Kleist, 1934). Unexpectedly, the authors found activation in the left ventral premotor area (Brodmann area 44, the posterior part of Broca's area) and the right (and to a lesser degree in the left) posterior temporal gyrus in addition to the bilateral parietal activation (Makuuchi, et al., 2003). These two regions were repeatedly reveled co-activated in the subsequent fMRI studies on drawing (Farias, et al., 2006; Harrington, et al., 2009; Miall, et al., 2009; Schaer, et al., 2012; Yuan and Brown, 2015). Because of their anatomical locations, we reason they are connected by the arcuate fasciculus which subserves language (Catani, et al., 2007). Here we obtain two insights. The first is that acquisition of language and drawing skill in the modern humans might result from the evolution of the arcuate fasciculus (Makuuchi, 2010; Rilling, et al., 2008). The second is that language and drawing may share similar fundamental computation in the brain, for instance building hierarchical structures of elements (e.g. words/strokes) for the externalization of mental representations by effectors (e.g. speech organs/hands) (Makuuchi, et al., 2003). These insights can be directly tested by neuroimaging methods. Researchers may be able to formulate hierarchical structure in drawing and examine if the processing of hierarchical structure in drawing activates Broca's area as in sentence processing (Friederici, et al., 2006; Makuuchi, et al., 2009; Zaccarella, et al., 2017) and if the activated regions in Broca's area have anatomical connections to the co-activated posterior regions.

\section{References}

Aubert, M., Brumm, A., Ramli, M., Sutikna, T., Saptomo, E.W., Hakim, B., Morwood, M.J., van den Bergh, G.D., Kinsley, L., Dosseto, A. (2014) Pleistocene cave art from Sulawesi, Indonesia. Nature, 514:223-7.

Balari, S., Benitez-Burraco, A., Camps, M., Longa, V.M., Lorenzo, G., Uriagereka, J. (2011) The archaeological record speaks: bridging anthropology and linguistics. International journal of evolutionary biology, 2011:382679. 
Berwick, R.C., Hauser, M.D., Tattersall, I. (2013) Neanderthal language? Justso stories take center stage. Frontiers in psychology, 4:671.

Catani, M., Allin, M.P., Husain, M., Pugliese, L., Mesulam, M.M., Murray, R.M., Jones, D.K. (2007) Symmetries in human brain language pathways correlate with verbal recall. Proceedings of the National Academy of Sciences of the United States of America, 104:17163-8.

De Renzi, E. (1997) Visuospatial and constructional disorders. In: Feinberg, T., Farah, M., editors. Behavioral Neurology and Neuropsychology. New York: McGraw-Hill. p 297-307.

Farias, D., Davis, C., Harrington, G. (2006) Drawing: its contribution to naming in aphasia. Brain and language, 97:53-63.

Friederici, A.D., Bahlmann, J., Heim, S., Schubotz, R.I., Anwander, A. (2006) The brain differentiates human and non-human grammars: functional localization and structural connectivity. Proceedings of the National Academy of Sciences of the United States of America, 103:2458-63.

Harrington, G.S., Farias, D., Davis, C.H. (2009) The neural basis for simulated drawing and the semantic implications. Cortex; a journal devoted to the study of the nervous system and behavior, 45:386-93.

Higham, T., Douka, K., Wood, R., Ramsey, C.B., Brock, F., Basell, L., Camps, M., Arrizabalaga, A., Baena, J., Barroso-Ruiz, C., Bergman, C., Boitard, C., Boscato, P., Caparros, M., Conard, N.J., Draily, C., Froment, A., Galvan, B., Gambassini, P., Garcia-Moreno, A., Grimaldi, S., Haesaerts, P., Holt, B., Iriarte-Chiapusso, M.J., Jelinek, A., Jorda Pardo, J.F., Maillo-Fernandez, J.M., Marom, A., Maroto, J., Menendez, M., Metz, L., Morin, E., Moroni, A., Negrino, F., Panagopoulou, E., Peresani, M., Pirson, S., de la Rasilla, M., Riel-Salvatore, J., Ronchitelli, A., Santamaria, D., Semal, P., Slimak, L., Soler, J., Soler, N., Villaluenga, A., Pinhasi, R., Jacobi, R. (2014) The timing and spatiotemporal patterning of Neanderthal disappearance. Nature, 512:306-9.

Higham, T., Jacobi, R., Julien, M., David, F., Basell, L., Wood, R., Davies, W., Ramsey, C.B. (2010) Chronology of the Grotte du Renne (France) and implications for the context of ornaments and human remains within the Chatelperronian. Proceedings of the National Academy of Sciences of the United States of America, 107:20234-9.

Hoffmann, D.L., Standish, C.D., Garcia-Diez, M., Pettitt, P.B., Milton, J.A., Zilhao, J., Alcolea-Gonzalez, J.J., Cantalejo-Duarte, P., Collado, H., de Balbin, R., Lorblanchet, M., Ramos-Munoz, J., Weniger, G.C., Pike, A.W.G. (2018) U-Th dating of carbonate crusts reveals Neandertal origin of Iberian cave art. Science (New York, N.Y.), 359:912-915.

Jaubert, J., Verheyden, S., Genty, D., Soulier, M., Cheng, H., Blamart, D., Burlet, C., Camus, H., Delaby, S., Deldicque, D., Edwards, R.L., Ferrier, C., Lacrampe-Cuyaubere, F., Leveque, F., Maksud, F., Mora, 
P., Muth, X., Regnier, E., Rouzaud, J.N., Santos, F. (2016) Early Neanderthal constructions deep in Bruniquel Cave in southwestern France. Nature, 534:111-4.

Kleist, K. (1934) Gehirnpathologie. Leipzig. Barth.

Makuuchi, M. (2010) fMRI studies on drawing revealed two new neural correlates that coincide with the language network. Cortex; a journal devoted to the study of the nervous system and behavior, 46:268-9.

Makuuchi, M., Bahlmann, J., Anwander, A., Friederici, A.D. (2009) Segregating the core computational faculty of human language from working memory. Proceedings of the National Academy of Sciences of the United States of America, 106:8362-7.

Makuuchi, M., Kaminaga, T., Sugishita, M. (2003) Both parietal lobes are involved in drawing: a functional MRI study and implications for constructional apraxia. Brain research. Cognitive brain research, 16:338-47.

Miall, R.C., Gowen, E., Tchalenko, J. (2009) Drawing cartoon faces--a functional imaging study of the cognitive neuroscience of drawing. Cortex; a journal devoted to the study of the nervous system and behavior, 45:394-406.

Prufer, K., Racimo, F., Patterson, N., Jay, F., Sankararaman, S., Sawyer, S., Heinze, A., Renaud, G., Sudmant, P.H., de Filippo, C., Li, H., Mallick, S., Dannemann, M., Fu, Q., Kircher, M., Kuhlwilm, M., Lachmann, M., Meyer, M., Ongyerth, M., Siebauer, M., Theunert, C., Tandon, A., Moorjani, P., Pickrell, J., Mullikin, J.C., Vohr, S.H., Green, R.E., Hellmann, I., Johnson, P.L., Blanche, H., Cann, H., Kitzman, J.O., Shendure, J., Eichler, E.E., Lein, E.S., Bakken, T.E., Golovanova, L.V., Doronichev, V.B., Shunkov, M.V., Derevianko, A.P., Viola, B., Slatkin, M., Reich, D., Kelso, J., Paabo, S. (2014) The complete genome sequence of a Neanderthal from the Altai Mountains. Nature, 505:43-9.

Rilling, J.K., Glasser, M.F., Preuss, T.M., Ma, X., Zhao, T., Hu, X., Behrens, T.E. (2008) The evolution of the arcuate fasciculus revealed with comparative DTI. Nature neuroscience, 11:426-8.

Schaer, K., Jahn, G., Lotze, M. (2012) fMRI-activation during drawing a naturalistic or sketchy portrait. Behavioural brain research, 233:209-16.

Soressi, M., McPherron, S.P., Lenoir, M., Dogandzic, T., Goldberg, P., Jacobs, Z., Maigrot, Y., Martisius, N.L., Miller, C.E., Rendu, W., Richards, M., Skinner, M.M., Steele, T.E., Talamo, S., Texier, J.P. (2013) Neandertals made the first specialized bone tools in Europe. Proceedings of the National Academy of Sciences of the United States of America, 110:14186-90.

Yuan, Y., Brown, S. (2015) Drawing and writing: An ALE meta-analysis of sensorimotor activations. Brain and cognition, 98:15-26. 
Zaccarella, E., Meyer, L., Makuuchi, M., Friederici, A.D. (2017) Building by Syntax: The Neural Basis of Minimal Linguistic Structures. Cerebral cortex (New York, N.Y. : 1991), 27:411-421. 